\title{
Penerapan Terapi Hipnosis Lima Jari Terhadap Penurunan Kecemasan Pasien Diabetes Militus
}

\author{
Hita Nadila ${ }^{1 *}$, Yuni Sandra Pratiwi ${ }^{2}$ \\ 1,2 Program Studi Diploma Tiga Keperawatan, Universitas Muhammadiyah Pekajangan \\ Pekalongan, Indonesia \\ *email: hitanadila999@gmail.com
}

\begin{abstract}
Diabetes mellitus is a metabolic disorder because the pancreas cannot produce insulin and when the body is unable to use it. It can be seen from the blood sugar levels. High blood sugar levels can cause damage to the human body system. Patients with diabetes mellitus have psychological disorders, especially anxiety disorders. The patients are afraid of their blood sugar levels that can rise and fall at any time. One of the nursing actions for diabetes mellitus patients who experience anxiety is five finger hypnosis therapy. The purpose of this case study is to describe the application of five-finger hypnosis therapy in reducing DM patients' anxiety. This study used a case study. The subject of this case study was two diabetes mellitus patients who experience anxiety. The results of the case study showed that there was a decrease in anxiety in diabetes mellitus patients after five finger hypnosis therapy was carried out. In conclusion, five-finger hypnosis therapy is effective for reducing anxiety in diabetes mellitus patients. This result can be used as consideration for health workers to provide five-finger hypnosis therapy to diabetes mellitus patients who experience anxiety.
\end{abstract}

Keywords: diabetes mellitus, anxiety, five finger hypnosis

\begin{abstract}
Abstrak
Diabetes militus adalah suatu kelainan metabolik karena pankreas tidak dapat memproduksi insulin dan ketika tubuh tidak mampu menggunakannya, yang biasa ditandai dengan peningkatan kadar gula darah yang dapat menyebabkan kerusakan bagi sistem tubuh manusia. Pasien diabetes militus memiliki gangguan psikologis terutama gangguan kecemasan, disebabkan karena pasien merasa takut kadar gula darahnya yang sewaktuwaktu bisa naik dan turun. Pemberian tindakan keperawatan pada pasien diabetes militus yang mengalami kecemasan salah satunya dengan terapi hipnosis lima jari. Tujuan dari studi kasus ini yaitu menggambarkan penerapan terapi hipnosis lima jari dalam menurunkan kecemasan pada pasien diabetes militus. Rancangan karya tulis ilmiah ini menggunakan studi kasus, dengan subjek studi kasus dua pasien diabetes militus yang mengalami kecemasan. Hasil studi kasus menunjukkan bahwa ada penurunan kecemasan pada pasien diabetes militus setelah dilakukan terapi hipnosis lima jari. Simpulan terapi hipnosis lima jari efektif untuk menurunkan kecemasan pada pasien diabetes militus. Saran bagi tenaga kesehatan diharapkan dapat dijadikan sebagai bahan referensi untuk melakukan menerapkan terapi hipnosis lima jari pada pasien diabetes militus yang mengalami kecemasan.
\end{abstract}

Kata kunci: diabetes militus, kecemasan, hipnosis lima jari.

\section{Pendahuluan}

Diabetes militus merupakan salah satu penyakit kronis dimana organ pankreas tidak dapat memproduksi cukup insulin atau ketika tubuh tidak efektif dalam menggunakannya (World Health Organizaztion, 2016). Diabetes militus atau yang 


\section{Prosiding Seminar Nasional Kesehatan Lembaga Penelitian dan Pengabdian Masyarakat Universitas Muhammadiyah Pekajangan Pekalongan

biasa dikenal dengan penyakit kencing manis, saat ini menjadi salah satu penyebab utama kematian diseluruh dunia (Wiyadi et al., 2013). Organisasi Internasional Diabetes Federation (IDF) tahun 2019 menyatakan bahwa diperkirakan sedikitnya terdapat 463 juta orang pada usia 20-79 tahun di dunia menderita diabetes atau setara dengan prevalensi sebesar 9,3\% dari total penduduk di usia yang sama, berdasarkan jenis kelamin IDF memperkirakan prevalensi DM ditahun 2019 yaitu 9\% pada perempuan dan $9,65 \%$ pada laki-laki, prevelensi diabetes militus diperkirakan akan terus meningkat seiring bertambahnya umur penduduk menjadi $19,9 \%$ atau 111,2 juta orang pada usia 65-79 tahun, angka tersebut akan diprediksi terus meningkat hingga mencapai 578 juta di tahun 2030 dan 700 juta ditahun 2045. Prevalensi penderita DM di Indonesia mencapai sekitar 10,7 juta jiwa (IDF, 2019).

Data diabetes militus di Kota Pekalongan tahun 2020 menepati urutan ke- 2 setelah penyakit hipertensi (Dinkes Kota Pekalongan, 2021). Prevelensi tertinggi penderita DM di Kota Pekalongan khususnya di wilayah kerja Puskesmas, berada di Puskesmas Bendan dengan jumlah 234 kasus, sedangkan penderita DM terendah berada di Puskesmas Noyontaan dengan jumlah 38 kasus terbaru di bulan Desember 2020 (Dinkes Kota Pekalongan, 2021). Tingginya prevelensi pasien diabetes militus di Bendan Kota Pekalongan perlu adanya upanya untuk meminimalisis masalah tersebut, sehingga tidak menyebabkan gangguan fisik maupun psikologis bagi penderita (Novitasari, 2017). Gangguan psikologis pada penderita diabetes militus salah satunya yaitu kecemasan. Kecemasan adalah perasaan takut yang tidak jelas dan tidak didukung oleh situasi (Videbeck 2008 diambil dari Prabowo, 2018).

Kecemasan yang terjadi pada pasien diabetes militus disebabkan karena penderita depresi terhadap kadar gula darah yang sewaktu-waktu bisa naik dan turun secara tiba-tiba yang akan menimbulkan komplikasi lain akibat dari kurangnya manajemen cara atau teknik untuk menghadapi permasalahannya (Mahmuda, Thohirun, \& Prasetyowati 2016 diambil dari Wahyuningsih \& Hidayati, 2019). Penderita diabetes militus yang mengalami kecemasan juga disebabkan karena banyak orang yang beranggapan bahwa penyakit diabetes militus tidak bisa disembuhkan dan hidup sengsara karena terbebani oleh penyakit diabetes militus, hal tersebut akan membuat stessor pembuat stress bekerja lebih jauh meningkat pada penderita (Novitasari, 2017). Kecemasan yang terjadi pada pasien diabetes militus merupakan salah satu faktor pemicu terjadinya pelepasan hormon epineprin dan noradrenalin sehingga dapat menyebabkan perubahan tingkat kadar gula dalam darah serta membuat tubuh menghentikan produksi insulin (Ludiana, 2017). Penderita diabetes militus yang mengalami kecemasan juga memiliki kontrol gula darah yang buruk dan meningkatkan gejala-gejala penyakit lainya (Black \& Hawk 2013 diambil dari Wiyadi et al., 2019).

Tanda dan gejala yang timbul pada pasien diabetes militus yang mengalami kecemasan di Kelurahan Bendan Kota Pekalongan yaitu pasien sering mengalami gangguan fisik, gangguan tidur, dan merasa takut, khawatir, dan merasa cemas. Hal tersebut juga dialami pada Tn. S dan Ny. U di Kelurahan Bendan Kota Pekalongan dengan hasil pengkajian yaitu pasien mengatakan cemas memikirkan penyakitnya dan takut gulanya tambah tinggi. Tingkat kecemasan pada Tn. S dan Ny. U yaitu kecemasan sedang. Fenomena yang terjadi pada penderita diabetes militus yang 


\section{Prosiding Seminar Nasional Kesehatan Lembaga Penelitian dan Pengabdian Masyarakat Universitas Muhammadiyah Pekajangan Pekalongan

mengalami kecemasan tidak bisa dianggap remeh, hal tersebut perlu adanya perhatian dan penangganan khusus bagi penderita, salah satunya dengan terapi hipnisis lima jari.

Hipnosis lima jari adalah pemberian perlakuan kepada seseorang dengan keadaan rileks, untuk memusatkan pikiran atau bayangan yang menyenangkan sambil menyentuh lima jari secara berurutan (Hastuti 2015 diambil dari Marbun et al., 2019). Terapi hipnosis lima jari dapat diberikan pada pasien diabetes militus yang mengalami kecemasan, karena ketika pasien melakukan terapi hipnosis lima jari dengan fokus dapat memberikan rasa tenang, rileks dan mengurangi kecemasan pada pasien, sehingga pasien dapat merawat dan mengontrol dirinya agar gula darahnya tetep stabil. Tindakan hipnosis lima jari ini sesui dengan penelitian Sarwati et al., (2020) menyatakan bahwa terdapat pengaruh penurunan tingkat kecemasan, setelah diberikan terapi hipnosis lima jari pada pasien diabetes militus yang mengalami kecemasan. Berdasarkan latar belakang diatas maka penulis tertarik untuk menyusun karya tulis ilmiah dengan judul "Penerapaan Terapi Hipnosis Lima Jari Terhadap Penurunan Kecemasan Pasien Diabetes Militus".

\section{Metode}

Rancangan penulisan karya tulis ilmiah yang dipilih yaitu studi kasus pada penerapan terapi hipnosis lima jari terhadap penurunan kecemasan pasien diabetes militus. Subjek studi kasus yang digunakan yaitu pasien diabetes militus yang mengalami kecemasan. Adapun kriteria inklusi dari studi kasus ini yaitu pasien diabetes militus dengan nilai GDS lebih dari $140 \mathrm{mg} / \mathrm{dl}$, pasien yang mengalami masalah cemas sedang berdasarkan skala HARS, dan pasien yang belum mendapatkan terapi hipnosis lima jari. Kriteria ekslusi dari studi kasus ini yaitu pasien diabetes militus yang tidak bersedia menjadi responden dan pasien yang tidak kooperatif.

Studi kasus ini di Kota Pekalongan dan waktu pelaksanaanya 2 kali intervensi, dengan jeda pemberian 1 minggu. Pengumpulan data pada studi kasus ini menggunakan metode wawancara atau interview dengan mendapatkan informasi secara lisan dari subjek penelitian dan keluarga subjek. Selain dengan metode wawancara peneliti juga melakukan dengan metode observasi dengan melihat, memperhatikan dan mencacat atau dokumentasi. Instrumen studi kasus dalam penelitian ilmiah ini adalah lembar kuesioner tingkat kecemasan, dengan skala HARS (Hamiton Anxiety Rating Scale, lembar SOP hipnosis lima jari, dan Lembar asuhan keperawatan. Pengolahan data dalam studi kasus ini menggunakan metode analisis meliputi data karakteristik demografi, tingkat kecemasan sebelum dan sesudah pemberian terapi hipnosis lima jari, dan analisa hasil sebelum dan sesudah diberikan terapi hipnosis lima jari.

\section{Hasil dan Pembahasan}

Hasil

Karakteristik responden berdasarkan data demografi dan tingkat kecemasan disajikan dalam tabel sebagai berikut. 
Tabel 3.1 Distribusi Frekuensi Responden Berdasarkan Data demografi $(n=2)$

\begin{tabular}{lcccc}
\hline & \multicolumn{4}{c}{ Karakteristik } \\
\cline { 2 - 5 } & Usia & Jenis kelamin & Pendidikan & Lama mengalami DM \\
\hline Responden 1 & 51 & Laki-laki & SMP & 1 tahun \\
Responden 2 & 60 & Perempuan & SD & 1 tahun \\
\hline
\end{tabular}

Hasil analisa tabel 3.1 memperlihatkan bahwa responden 1 dan 2 memiliki persamaan lama mengalami diabetes militus yaitu selama 1 tahun, dan memiliki perbedaan pada responden 1 dan 2 yaitu usia pada responden 1 berusia 51 tahun dan responden 2 berusis 60 tahun. Perbedaan responden 1 dan 2 yaitu jenis kelamin, responden 1 laki-laki dan responden 2 perempuan. Perbedaan lain pada responden 1 dan 2 yaitu jenjang pendidikan, dengan responden 1 tamat SMP dan responden 2 tamat SD.

Tabel 3.2 Distribusi Frekuensi Responden Berdasarkan Tingkat Kecemasan $(n=2)$

\begin{tabular}{ccc}
\hline Tingkat kecemasan & Pre-test & Post- test \\
\hline Tidak ada kecemasan & & 1 \\
Ringan & 2 & \\
Sedang & & \\
Berat & \\
Panik atau berat sekali & 2 & 2 \\
\hline Total & 2
\end{tabular}

Hasil analisa tabel 3.2 memperlihatkan bahwa sebelum dilakukan terapi hipnosis lima jari pada responden 1 mengalami tingkat kecemasan sedang dan setelah dilakukan terapi hipnosis lima jari mengalami tingkat kecemasan tidak ada. Analisa data tingkat kecemasan memperlihatkan bahwa sebelum dilakukan terapi hipnosis lima jari pada responden 2 mengalami tingkat kecemasan sedang dan setelah dilakukan terapi hipnosis lima jari mengalami tingkat kecemasan ringan.

\section{Pembahasan}

\section{Karakterik Demografi}

Analisa data responden pada penulisan karya tulis ilmiah ini ditinjau berdasarkan karakteristik demografi memperlihatkan bahwa responden 1 dan 2 memiliki persamaan lama mengalami penyakit diabetes militus yaitu 1 tahun. Ditemukan perbedaan usia dengan responden 1 berusia 51 tahun dan responden 2 berusia 60 tahun. Usia sangat berpengaruh pada tingkat kecemasan responden, yang artinya semakin bertambah usia responden maka semakin rendah tingkat kecemasan. Pernyataan tersebut sesui dengan penelitian Bachri et al., (2017) menyatakan bahwa semakin bertambah usia 


\section{Prosiding Seminar Nasional Kesehatan Lembaga Penelitian dan Pengabdian Masyarakat Universitas Muhammadiyah Pekajangan Pekalongan

seseorang maka semakin matang proses pikir dan bertindak dalam menghadapi masalah, sehingga semakin bertambah usia pasien maka semakin berkurang tingkat kecemasannya. Perbedaan lain yang ditemukan pada jenis kelamin responden 1 lakilaki dan responden 2 perempuan. Terdapat hubungan tingkat kecemasan dengan jenis kelamin. Wahyuningsih dan Hidayati (2019) menyatakan bahwa perempuan lebih beresiko mengalami kecemasan dibandingkan laki-laki, karena perempuan memiliki kualitas hidup yang rendah, terutama dalam aspek mental dan psikologi dimana perempuan lebih mudah mengalami cemas dari pada laki-laki. Perbedaan lainnya yang ditemukan pada responden 1 dan 2 yaitu jenjang pendidikan dengan responden 1 tamat pendidikan SMP dan responden 2 tamat pendidikan SD. Latar belakang tingkat pendidikan seseorang berhubungan dengan pengetahuan pada dirinya semakin tinggi, sehingga semakin tinggi tingkat pendidikan maka semakin rendah tingkat kecemasannya (Suyani, 2020).

\section{Analisa Perbedaan Tingkat Kecemasan Sebelum dan Sesudah Pemberian Terapi Hipnosis Lima Jari}

Kecemasan atau ansietas adalah perasaan takut yang tidak jelas dan tidak didukung oleh situasi (Videbeck 2008 diambil dari Prabowo, 2018). Tingkat kecemasan yang dialami oleh responden 1 sebelum dilakukan terapi hipnosis lima jari berada pada tingkat kecemasan sedang dan setelah diberikan terapi hipnosis lima jari berada pada tingkat tidak cemas. Tingkat kecemasan yang dialami responden 2 sebelum dilakukan terapi hipnosis lima jari berada pada tingkat kecemasan sedang dan setelah dilakukan terapi hipnosis lima jari berada pada tingkat kecemasan ringan. Hal tersebut membuktikan bahwa terdapat penurunan tingkat kecemasan pada pasien diabetes militus setelah dilakukan terapi hipnosis lima jari. Hasil penerapan terapi hipnosis lima jari ini sesuai dengan penelitian Saswati et al., (2020) yang membuktikan bahwa terdapat pengaruh terapi hipnosis lima jari terhadap penurunan kecemasan pada pasien diabetes militus yang mengalami cemas. Perbedaan tingkat kecemasan setelah dilakukan terapi hinosis lima jari pada responden 1 dan responden 2 dipengaruhi oleh karakteristik demografi pada kedua responden. Data demografi pada kedua responden dipengaruhi oleh latar belakang pendidikan yang dimiliki responden 1 dan 2, dengan responden 1 memiliki jenjang pendidikan tamat SMP dan responden 2 tamat SD. Lingkungan pendidikan kedua responden yang berbeda memberikan pengaruh teradap tingkat kecemasan dengan konflik emosi yang dialami responden. Teori tersebut sesui dengan penelitian Vellyana el al., (2017) menyatakan bahwa tingkat pendidikan individu berhubungan terhadap kemampuan berpikir seseorang, sehingga akan berpengaruh terhadap tingkat kecemasan dan emosi seseorang.

\section{Analisa Efektivitas Penerapan Hipnosis Lima Jari}

Penerapan terapi hipnosis lima jari dapat menurunkan kecemasan pada pasien diabetes militus terhadap kedua responden. Hal tersebut dibuktikan dengan adanya hasil pengukuran tingkat kecemasan sebelum (pre-test) dan sesudah (post-test) diberikan terapi hipnosis lima jari. Hal tersebut terjadi karena terapi hipnosis lima jari 


\section{Prosiding Seminar Nasional Kesehatan Lembaga Penelitian dan Pengabdian Masyarakat Universitas Muhammadiyah Pekajangan Pekalongan

merupakan terapi yang memanfaatkan kekuatan pikiran dengan menggerakkan jari tangan melalui komunikasi yang melibatkan semua indra seperti penglihatan, penciuman, dan pendengaran, sehingga dapat memulihkan diri dan menjaga kesehatan atau keadaan pikiran menjadi rileks. Jumlah penurunan tingkat kecemasan yang dialami responden 1 dan 2 memiliki perbedaan dimana responden 1 sebelum (pre-test) tingkat cemas sedang dan sesudah (post-test) tingkat kecemasan tidak ada. Sedangkan responden 2 sebelum (pre-test) tingkat cemas sedang dan sesudah (posttest) tingkat cemas ringan. Tingkat keberhasilan terhadap penerapan terapi hipnosis lima jari dipengaruhi oleh lingkungan tempat tinggal kedua responden, dengan responden 1 tidak padat penduduk dan responden 2 cukup padat penduduk, dimana lingkungan yang tenang dapat memaksimalkan tindakan terapi hipnosis lima jari pada responden. Hal tersebut sesui dengan teori bahwa keberhasilan terapis didukung karena beberapa faktor yaitu adannya kerja sama antra kelompok responden yang baik, suasana yang tenang dan kondusif, sehingga responden dapat berkonsentrasi dan dapat melakukan hipnosis lima jari secara maksimal (Wahyuningsingsih \& Hidayati, 2019).

\section{Kesimpulan}

Penilaian tingkat kecemasan pada responden 1 dan 2 sebelum diberikan terapi hipnosis lima jari kedua responden memiliki tingkat kecemasan sedang, sedangkan penilaian tingkat kecemasan responden 1 dan 2 setelah diberikan terapi hipnosis lima jari yaitu sama-sama mengalami penurunan tingkat kecemasan, dengan responden 1 tingkat cemas menjadi tidak ada kecemasan dan responden 2 tingkat cemas menjadi kecemasan ringan. Terapi hipnosis lima jari efektif dalam menurunkan tingkat kecemasan pada pasien diabetes militus. Saran bagi tenaga kesehatan diharapkan dapat dijadikan sebagai bahan referensi untuk melakukan menerapkan terapi hipnosis lima jari pada kecemasan.

\section{Referensi}

Bachri, S., Zainul, C., Abdul, R. (2017). Perbedaan Tingkat Kecemasan Pasieb Berdasarkan Usia, Jenis Kelamin, Tingkat Pendidikan, dan Pengalaman Pencabutan. Jurnal Pustaka Kesehatan. 5 (1), 138-144. Diambil dari http://jurnal.unej.ac.id

Dinkes Kota Pekalongan. (2021). Research/Survey dari Perencanaan, Pembangunan, Penelitian, dan Pengembangan Daera Kota Pekalongan. Pekalongan: P2 Dinkes Kota Pekalongan.

Internasional Diabetes Federation. (2019). Infodatin Pusat Data dan Informasi Kementrian Kesehatan RI: Tetap Produktif, Cegah, dan Atasi Diabetes Militus. Diambil dari https://www.kemkes.go.id

Ludiana. (2017). Hubungan Kecemasan dengan Kadar Glukosa Darah Penderita Diabetes Mellitus di Wilayah Kerja Puskesmas Sumbersari Bantul Kecamatan Metro Selatan Kota metro. Wacana Kesehatan, 1(1), 118-130. Diambil dari http://jurnal.akperdharmawacana.ac.id 


\section{Prosiding Seminar Nasional Kesehatan Lembaga Penelitian dan Pengabdian Masyarakat Universitas Muhammadiyah Pekajangan Pekalongan

Marbun, A.S., Jek, A.P., Surya, I.P. (2019). Evektivitas Terapi Hipnotis Lima Jari Terhadap Kecemasan Ibu Pre Partum di Klinik Chelsea Husada Tanjung Beringin Kabupaten Serdang Bedagai. Jurnal Keperawatan Prioriy, 2 (2), 92-99. Diambil dari http://jurnal.unprimdn.ac.id

Novitasari, R. (2017). Diabetes Militus. Yogyakarta : Nuha Medika.

Prabowo, E. (2018). Konsep dan Aplikasi Asuhan Keperawatan Jiwa. Yogyakarta : Nuha Medika.

Riskesdas. (2019). Laporan Provinsi Jawa Tengah Riskesdas 2018. Diambil dari http://ejournal2.litbang.kemkes.go.id

Saswati, N., Sutinah, Dasuki. (2020). Pengaruh Penerapan Hipnosis Lima Jari untuk Menurunkan Kecemasan Diabetes Militus. Jurnal Endurance: Kajian IImiah Problem Kesehatan, 5(1), 136-143. doi: 10.22216/jen.v5i1.4632.

Suyani. (2020). Hubungan Tingkat Pendidikan dan Status Pekerjaan dengan Kecemasan pada Ibu Hamil Trimester III. Jurbal Kesehatan Masyarakat. 9 (1): 258-992. doi:10.31596/jkm.v8i1.563.

Vellyana, D., Arena, L., Asri, R. (2017). Faktor-Faktor yang Berhubungan dengan Tingkat Kecemasan Pada Pasien Preoperative Di RS Mitra Husada Pringsewu. Jurnal Kesehatan, 8 (1) 108-113.diambil dari http://jurnal.unej.ac.id

Wahyuningsih, E., Erni, H. (2019). Hipnosis lima Jari Terhadap Penurunan Cemas Pada Pasien Diabetus Militus. Jurnal IImiah Permas: Jurnal IImiah STIKES Kendal, 9 (5), 395-400. Diambil dari https://journal.stikeskendal.ac.id

WHO. (2016). Info Dating Pusat Data dan Informasi Kementrian Kesehatan RI: Hari Diabetes Sedunia. Diambil dari https://pusdatin.kemkes.go.id

Wiyadi., Rina L., Junita L. (2013). Hubungan Tingkat Kecemasan dengan Kadar Gula Darah pada Penderita Diabetes Militus. Jurnal Husada Mahakam, 3, (6), 263 318. Diambil dari http://husadamahakam.poltekkes-kaltim.ac.id 